\title{
Effect of Summer Pruning on the Next Season's Shoot Growth of Young Apple Trees
}

\author{
Takuro Kikuchi, Takenori Asada, Yunosuke Shiozaki, \\ Toshiaki SAIto* and Shokichi Kamata** \\ Faculty of Agriculture, Hirosaki University, Hirosaki 036
}

\begin{abstract}
Summary
Two experiments were carried out with young apple trees (Fuji/Malus prunifolia Borkh. var. ringo) to examine the effect on the next season's shoot growth of summer and dormant thinning-out pruning, leaving short stubs. In Experiment 1 with 1-yearold trees, 4 lateral shoots which had been allowed to grow were cut, leaving $1 \sim 2 \mathrm{~cm}$ stubs on 8 occasions in the period between early July and late May in the next spring, while the terminal shoot was kept unpruned. The next season's shoot growth was weaker on the trees pruned in late August or earlier as compared with those pruned between late September and late March. In Experiment 2 with 2-year-old trees, which consisted of the central leader and 2 side branches, pruning was applied on 6 occasions in the period between late June and late November. All the shoots longer than $20 \mathrm{~cm}$ were cut, leaving $2 \sim 3 \mathrm{~cm}$ stubs except the terminal ones of the central leader and of two side branches. The next season's shoot growth was weaker on the trees pruned in late July or earlier than on the trees pruned between late August and late November. It was concluded that summer pruning does not invigorate the next season's shoot growth if it is applied early enough in the season for a balanced root: shoot ratio to be restored by the resultant regrowth.
\end{abstract}

\section{Introduction}

It has widely been accepted that summer pruning of deciduous fruit trees does not invigorate the next season's shoot growth and, therefore, can be safely used to restrict the size of a tree crown or to remove unwanted shoots without undesirable invigoration. Recently, however, several authors have reported on apple trees that no substantial differences were found between summer and dormant pruning in their effect on the next season's shoot growth. These circumstances were discussed by Saure(11) and Marini and Barden (7) in their comprehensive review on summer pruning.

The purpose of the present study was to compare the effect on the next season's shoot growth of summer and dormant pruning.

Received for publication October 20, 1988.

* Present address: Fujisaki Agricultural High School, Fujisaki, 038-38.

** Present address: School for the Handicapped of Aomori, Aomori 030.
Lateral shoots were thinned out leaving $1 \sim 3$ $\mathrm{cm}$ stubs because this type of summer pruning was considered useful for improving the light condition of the tree crown or removing unnecessary vigorous shoots in the process of developing framework branches of central leader trees.

\section{Materials and Methods}

\section{Experiment 1}

One-year-old Fuji trees on Malus prunifolia Borkh. var. ringo, grafted in the spring of 1978, were planted on April 11th, 1979 on alluvial soil, with distances of $1.2 \mathrm{~m}$ between rows and $0.4 \mathrm{~m}$ within rows. At planting, trees were cut back to $80 \mathrm{~cm}$ above the graft union and secondary roots were trimmed to the length of $5 \mathrm{~cm}$. To confine the roots in the soil allotted to each tree, plates of plastics with the dimensions of $0.6 \mathrm{~m} \times 0.6 \mathrm{~m}$ were inserted into the soil between trees in the row.

Five shoots at the top of trees were allowed to grow with other shoots below them being rubbed off. Of these shoots, four except the 




Fig. 1. Diagram to show the positions of measurement of shoots at the end of the second season (1980).

(1) Terminal shoot of the central leader.

(2) Total shoot length on the previous season's section.

(3) Total shoot length of the whole tree.

terminal shoot were cut back to $1 \sim 2 \mathrm{~cm}$ stubs on 8 occasions in the period between July of 1979 and May of 1980, forming 9 treatments as listed below: (1) Unpruned: five shoots at the top of trees were left unpruned, $(2 \sim 9)$ pruning in early July, late July, late August, late September, late October, late November, late March and late May, respectively. Each treatment was replicated 10 times in a two-tree randomized complete block design.

Half of the summer-pruned and unpruned trees ( 5 replications for each treatment) were dug up in early December in 1979 and measurements were taken of shoot length and dry weight of various parts of the trees. To estimate dry weight of various parts at the time of planting, relations between the dias meter and dry weight of various tree parts were examined on 30 extra trees. The remaining trees ( 5 replications) were grown through the next season. Measurements of shoot length were taken in December, 1980 at positions as diagrammatically shown in Fig. 1.

\section{Experiment 2}

One-year-old Fuji trees on Malus prunifolia grafted in the spring of 1980 were planted on April 10th, 1981 on alluvial soil with the distances of $1.5 \mathrm{~m}$ between rows and $1.0 \mathrm{~m}$ within rows. The trees were cut back at planting to $80 \mathrm{~cm}$ above the graft union.

Three shoots at the top of the trees were allowed to grow to form the central leader and two side branches. In the next season (1982), pruning treatments were applied on 6 occasions in the period between June and November. Treatments thus established were: late June, late July, late August, late September, late October, and late November. In each treatment, shoots longer than $20 \mathrm{~cm}$, except the terminal shoots of the central leader and two side branches, were cut back to $2 \sim 3 \mathrm{~cm}$ stubs. A randomized complete block design was used with 10 single-tree replicates per treatment.

At the end of the next growing season (1983), shoot growth was measured at the positions on the tree as diagrammatically shown in Fig. 5.

\section{Results}

Experiment 1

1. Results in the first growing season (1979).

Table 1 shows the lengths of shoots removed in treatments between July and September.

Table 1. Total shoot length removed in summer. pruning treatments (1979).

\begin{tabular}{lc}
\hline Treatment & $\begin{array}{c}\text { Total shoot length removed } \\
(\mathrm{cm})\end{array}$ \\
\hline Early July pruning & 83.3 \\
Late July pruning & 117.5 \\
Late August pruning & 196.3 \\
Late September pruning & 229.2 \\
\hline
\end{tabular}

Table 2. Terminal shoot length and total regrowth length in Summer-pruned trees (measured in November, 1979).

\begin{tabular}{lcc}
\hline \multicolumn{1}{c}{ Treatment } & Terminal shoot length $(\mathrm{cm})$ & Length of regrowth $(\mathrm{cm})$ \\
\hline Uupruned & $93.2 \mathrm{~b}^{\mathrm{z}}$ & $181.8 \mathrm{a}$ \\
Early July pruning & $93.7 \mathrm{~b}$ & $183.2 \mathrm{a}$ \\
Late July pruning & $91.6 \mathrm{~b}$ & $83.2 \mathrm{~b}$ \\
Late August pruning & $101.5 \mathrm{a}$ & 1.0 \\
Late September pruning & $97.6 \mathrm{ab}$ & \\
\hline
\end{tabular}

\footnotetext{
z Mean separation within columns by Duncan's multiple range test at $5 \%$ level.
} 
Table 3. Effects of summer pruning on the current year's tree growth (measured in December, 1979).

\begin{tabular}{|c|c|c|c|c|}
\hline \multirow[b]{2}{*}{ Treatment } & \multirow{2}{*}{$\begin{array}{l}\text { Dry weight of } \\
\text { whole tree }(\mathrm{g})^{\mathrm{z}}\end{array}$} & \multicolumn{3}{|c|}{ Increase in dry weight of tree parts $(\mathrm{g})$} \\
\hline & & trunk & $\begin{array}{l}\text { Current } \\
\text { year's shoots }\end{array}$ & new roots \\
\hline Unpruned & $183.9 \mathrm{a}^{\mathrm{x}}$ & $29.8 \mathrm{a}$ & $34.2 \mathrm{a}$ & $33.2 \mathrm{a}$ \\
\hline Early July pruning & $145.6 \mathrm{~b}$ & $20.4 \mathrm{bc}$ & $26.8 \mathrm{~b}$ & $23.6 \mathrm{bc}$ \\
\hline Late July pruning & $143.5 \mathrm{~b}$ & $18.2 \mathrm{c}$ & 23. $3 \mathrm{bc}$ & $22.1 \mathrm{c}$ \\
\hline Late August pruning & $140.1 \mathrm{~b}$ & $19.9 \mathrm{bc}$ & $17.6 \mathrm{~cd}$ & $22.6 \mathrm{bc}$ \\
\hline Late September pruning & $152.3 \mathrm{~b}$ & $27.2 \mathrm{ab}$ & $14.5 \mathrm{~d}$ & $28.6 \mathrm{ab}$ \\
\hline
\end{tabular}

z Leavess are not included.

y Shoots removed by treatments and leaves are not included.

x Mean separation within columns by Duncan's multiple range test at $5 \%$ level.

Table 4. Root: shoot ratios at the end of the first growing season ${ }^{2}$.

\begin{tabular}{|c|c|c|c|c|c|}
\hline \multicolumn{6}{|c|}{ Treatment (Time of pruning) } \\
\hline Unpruned & Early July & Late July & Late Aug. & Late Sept. & $\begin{array}{l}\text { Between Oct. }{ }^{x} \\
\text { and March } \\
\text { (After pruning) }\end{array}$ \\
\hline $1.01 b^{y}$ & $0.91 \mathrm{c}$ & $0.95 \mathrm{c}$ & $1.30 \mathrm{~b}$ & $1.98 \mathrm{a}$ & 2.29 \\
\hline
\end{tabular}

Table 2 shows the final lengths of terminal shoots and the total length of regrowth (secondary shoots from pruning stubs). The August-pruned trees produced longer terminal shoots, suggesting a compensatory growth acceleration after the loss of lateral shoots.

Table 3 shows the dry weight increase of different tree parts. Pruning in July and August reduced dry weight increase of the trunks (thickening of trunk) and dry weight of the new roots remarkably.

Table 4 gives root: shoot ratios at the end of the first growing season, calculated from the dry weight of new roots and shoots measured in early December. The root: shoot ratios of the July-pruned trees and those of the unpruned trees are similar to each other and much lower than the values for the trees pruned in September or later. The Augustpruned trees show a little higher value as compared with the July-pruned counterparts.

2. Results in the second growing season (1980).

In the second season, shoot growth was measured only at the end of the season. The length of the terminal shoot of the central leader (1) in Fig. 1) is shown in Fig. 2. There was a tendency for the trees pruned in

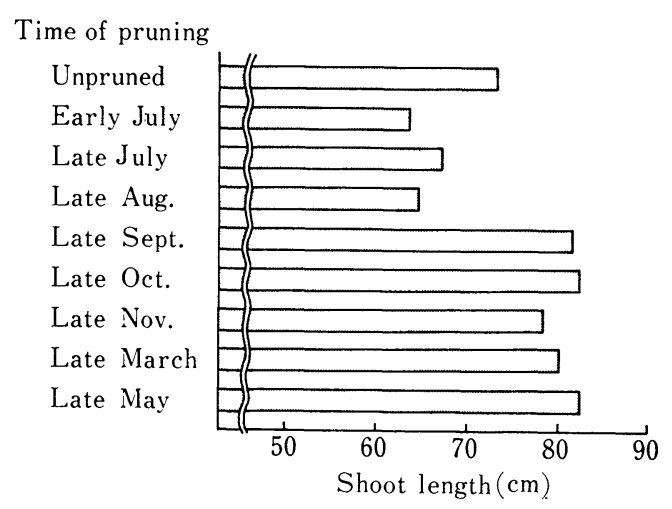

Fig. 2. Effect of diffesent times of pruning on terminal shoot length of the central leader (1980).

July and August to develop shorter shoots than those pruned between September and May, though significant differences were not detected among treatments.

Fig. 3 shows the total length of shoots on the previous season's section of the central leader (2) in Fig. 1). The values are smaller in the trees pruned in July and August than in those pruned between September and March. The values for the trees unpruned and pruned in May were comparable with the July- and August-pruned trees. The numbers of shoots 


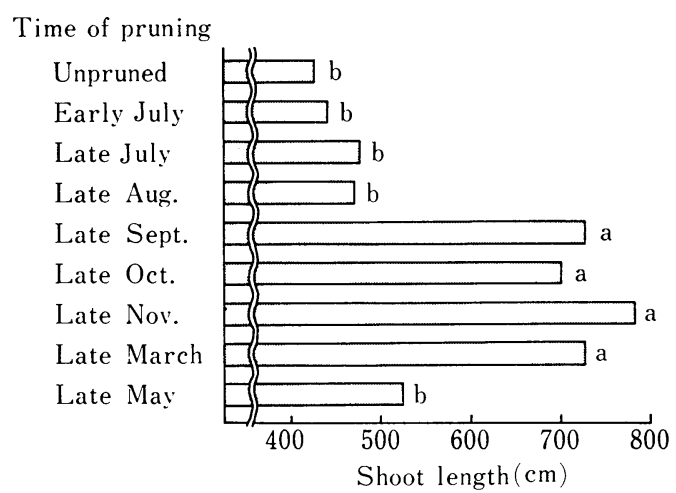

Fig. 3. Effect of different times of pruning on total shoot length on the previous season's section of the central leader at the end of the second season (1980).

$(>1 \mathrm{~cm})$ on this tree section are shown in Table 5. The values are the greatest for the trees pruned between October and March.

Fig. 4 shows the total shoot length of whole trees. The relationships between different pruning times were similar to those found for the total shoots on the central leader, except that unpruned trees had the greatest value. The total numbers of shoots $(>1 \mathrm{~cm})$ are shown in Table 5 . The unpruned trees produced the largest number, followed by those pruned in July, reflecting the amount of the
Time of pruning

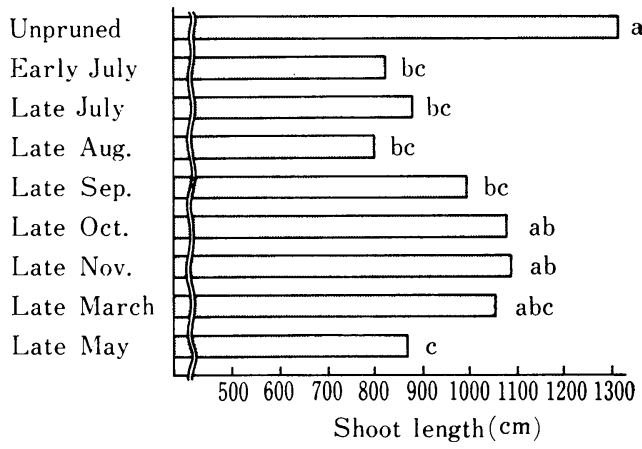

Fig. 4. Effect of different times of pruning on total shoot length of a whole tree at the end of the second season (1980).

previous season's shoot growth whether primary or secondary.

Experiment 2

1. Results in the first season (1982).

The total of the terminal shoot length of the central leader and two side branches and the total length of regrowth from pruning stubs are given in Table 6. Of the former, there were no differences among treatments. The amount of regrowth was much greater on the trees pruned in June and July than August-pruned ones.

2. Results in the second season (1983).

The length of terminal shoots is given in

Table 5. Number of shoots $(1 \mathrm{~cm})$ on the whole tree and central leader in the second growing season (1980).

\begin{tabular}{llllllllll}
\hline & & \multicolumn{1}{c}{ Treatment (Time of pruning) } \\
& unpruned & early & late & late & late & late & late & late & late \\
& & July & July & Aug. & Sept. & Oct. & Nov. & March & May \\
\hline Whole tree & $37.8 \mathrm{a}^{\mathrm{y}}$ & $31.1 \mathrm{~b}$ & $31.6 \mathrm{~b}$ & $27.1 \mathrm{bc}$ & $23.7 \mathrm{c}$ & $27.6 \mathrm{bc}$ & $23.1 \mathrm{c}$ & $27.0 \mathrm{bc}$ & $16.2 \mathrm{~d}$ \\
Central leader $^{z}$ & $13.8 \mathrm{~cd}$ & $15.2 \mathrm{bc}$ & $15.5 \mathrm{bc}$ & $14.4 \mathrm{bc}$ & $17.4 \mathrm{ab}$ & $18.3 \mathrm{a}$ & $18.3 \mathrm{a}$ & $20.3 \mathrm{a}$ & $11.4 \mathrm{~d}$ \\
\hline
\end{tabular}

¿ Previous season's section of the central leader.

y Mean separation within rows by Duncan's multiple range test at $5 \%$ level.

Table 6. Length of terminal shoots and regrowth in the first growing season (1982).

\begin{tabular}{|c|c|c|c|c|c|c|}
\hline & \multicolumn{6}{|c|}{ Treatment (Time of pruning) } \\
\hline & $\begin{array}{l}\text { late } \\
\text { June }\end{array}$ & $\begin{array}{l}\text { late } \\
\text { July }\end{array}$ & $\begin{array}{l}\text { late } \\
\text { Aug. }\end{array}$ & $\begin{array}{l}\text { late } \\
\text { Sept. }\end{array}$ & $\begin{array}{l}\text { late } \\
\text { Oct. }\end{array}$ & $\begin{array}{l}\text { late } \\
\text { Nov. }\end{array}$ \\
\hline Terminal shoots $(\mathrm{cm})^{z}$ & 292 & 276 & 303 & 277 & 292 & 268 \\
\hline Regrowth $(\mathrm{cm})^{\mathrm{y}}$ & $555 \mathrm{a}^{\mathrm{x}}$ & $447 \mathrm{a}$ & $191 b$ & $5 c$ & $0 \mathrm{c}$ & $0 \mathrm{c}$ \\
\hline
\end{tabular}

$z$ The total of terminal shoots of the central leader and 3 side branches.

y The total of regrowth from pruned stubs.

$\times$ Mean separation within rows by Duncan's multiple range test at $5 \%$ level. 


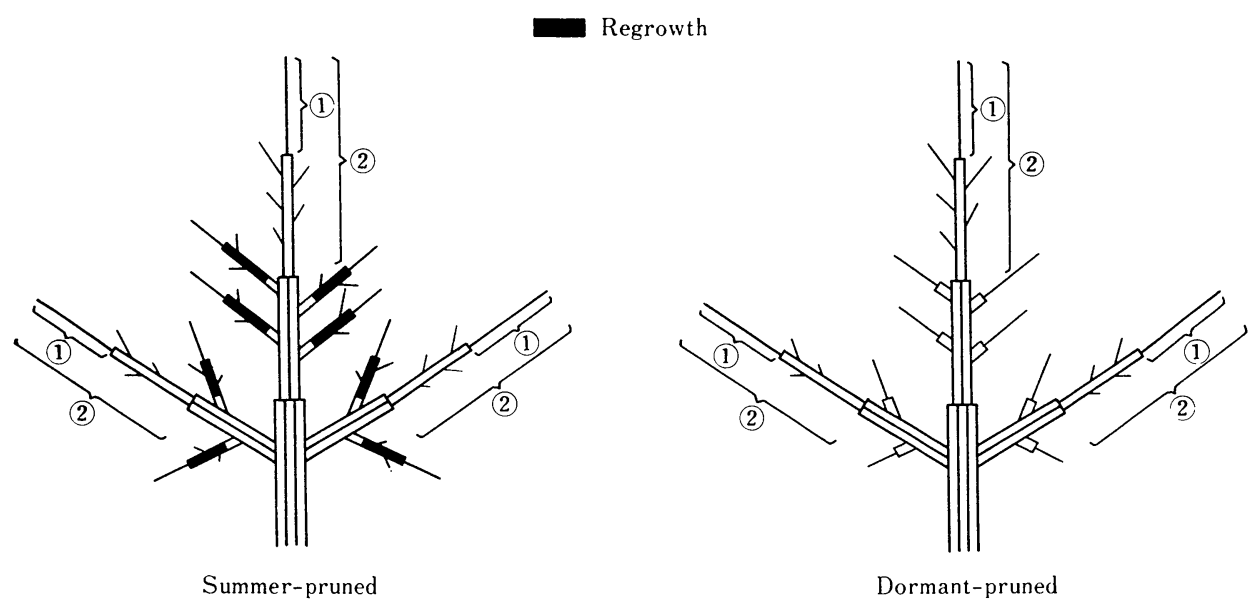

Fig. 5. Diagram to show the positions of measurement of shoots at the end of the second season (1983). (1) Terminal leaders of the central leader and two side branches.

(2) Total length of shoots on the previous season's section of the central leader and two side branches.

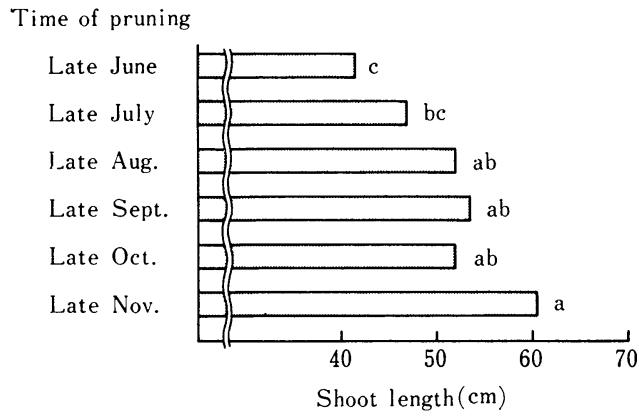

Fig. 6. Effect of different times of pruning on terminal shoot length ${ }^{1}$ of the central leader and two side branches at the end of the second season (1983).

1 Average of top three shoots each of the central leader and two side branches.

Fig. 6. They were obtained as the average length of the top three shoots, each of the central leader and two side branches (1) in Fig. 5). The trees pruned in June produced shorter shoots than those pruned in August or later. There is also a significant difference between the July-pruned and November-pruned trees.

Fig. 7 shows the total length of shoots $(>0.5$ $\mathrm{cm}$ ) on the previous season's section of the central leader and two side branches (2) in Fig. 5). The trees pruned in June and July developed less extension growth than those pruned in August or later.

Significant differences were not detected among different pruning times in total shoot



Fig. 7. Effect of different times of pruning on total shoot length on the previous season's section of the central leader at the end of the second season (1983).

length of a whole tree.

\section{Discussion}

The effect of thinning-out pruning leaving short stubs at different times on the next season's shoot growth was best detected in the total shoot length, rather than the terminal shoot alone, on the previous season's section of the central leader and side branches. This indicates that the growth of lateral shoots responds to this type of pruning more sharply than the terminal shoot does. This was most typically demonstrated by the late-May pruning, a kind of delayed dormant pruning, in Experiment 1. The choice of shoots to be measured is considered a matter of vital im- 
portance when comparison is made among different pruning treatments.

Marini amd Barden(6) reported that summer pruning of young as well as mature apple trees did not suppress shoot growth the next season. They suggested a negative view on the traditional concept that summer pruning suppresses the next season's shoot growth through lowering the level of reserved food, stating that relatively low levels of carbohydrates in the roots are adequate for normal spring growth. The result of Expxeriment 2, where pruning in August or later showed a similar invigorating effect, seems to support this view in consideration of the fact that accumulation of carbohydrates in the roots starts in late summer or early antumn in young apple trees $(8,13)$.

Kramer and Kozlowski(3) suggested that plants of various species have characteristic root: shoot ratios and that, if the ratio is drastically altered, physiological changes occur that lead to compensatory growth and tend to slowly bring the root: shoot ratio back into its characteristic balance. It is considered in this connection that after summer pruning the original root: shoot ratio is restored in the same season if enough time is given for regrowth. This concept seems to be applicable to the next season's shoot growth after summer pruning when considering the fact that in Experiment 1 the root: shoot ratio as well as the vigor of shoots the next aeason was similar to each other among July- and August-pruned trees and unpruned ones.

In Experiment 2, however, August pruning caused vigorous shoot growth the next season which was comparable with pruning in September or later. The conflicting results in the two experiments can be explained as follows. In Experiment 1, newly planted oneyear old trees without established root systems were used, and pruning was so heavy as to remove four out of five shoots. Accordingly, root growth was suppressed severely and root: shoot ratio was not raised significantly despite reduced regrowth after August pruning. In Experiment 2, however, it is assumed that reduction of new shoot growth after summer pruning was not so severe because a considerable amount of roots was expected to have been produced in the spring(2), and, in addi- tion, pruning itself was relatively light since shoots less than $20 \mathrm{~cm}$ and spurs were left uncut. Reduction of regrowth after August pruning, therefore, must have raised root: shoo ratio, leading to vigorous growth in the next season.

In conclusion, summer pruning does not invigorate the next season's shoot growth if it is applied early enough in the season to restore a balanced root: shoot ratio which is comparable with that of unpruned counterparts. On the other hand, it exerts an invigorating effect similar to dormant pruning if it is practiced so late as to cause a higher root: shoot ratio.

Some earlier studies, in which no substantial differences were detected between summer and winter prunings with regard to their effect on the next season's shoot growth, seem to involve some problems from a methodological point of view. In some of them summer pruning was carried out in mid-August(5), late August(6), supposedly mid- or late August (100 to 105 days after full bloom) (12), or early September (10). These times of pruning may have been too late in view of the recovery of balanced root: shoot ratios. In some studies, summer pruning was compared with nopruning(4), not with dormant pruning, including the case where light dormant pruning was applied to all treatments including unpruned control(1).

Most of the earlier studies of summer pruning utilized heading-back pruning, and the next season's shoot growth was often measured in the proximity of the cuts. The differences in the type of pruning and the choice of shoots to be measured may have been factors in the inconsistency of results between different investigations. Another point to be considered here is the fact that severe dormant headingback, as compared with comparable summer pruning, can delay sprouting of buds below the cuts as was revealed by Marini(5) and Saure(10).

\section{Acknowledgement}

The authors wish to thank Dr. Max Saure for his valuable suggestions rendered during the course of the investigations.

\section{Literature Cited}

1. Greene, W.G. and W.J. LORD. 1983. Effects 
of dormant pruning, summer pruning, yield, and fruit quality of 'Delicious' and 'Cortland' apple trees. J. Amer. Soc. Hort. Sci. 108: 590-595.

2. HEAD, G.C. 1969. Effects of fruiting and defoliation on seasonal trends in new root production on apple trees. J. Hort. Sci. 44: 175-181.

3. KRAmER, P.J. and T.T. KOZlowski. 1979. Physiology of Woody Plants. p. 590-591. Academic Press, New York.

4. LORD, W.J. and D.W. GreEnE. 1979. Flowering of young apple trees following summer pruning. J. Amer. Soc. Hort. Sci. 104: 540-544.

5. MARINI, R.P. and J.A. BARDEN. 1982. Growth and flowering of vigorous apple trees as affected by summer or dormant pruning. J. Amer. Soc. Hort. Sci. 107 : 34-39.

6. MARINI, R.P. and J.A. BARDEN. 1982. Effects of summer vs. dormant pruning and NAA treatment on growth of one- and two-year-old apple trees. J. Amer. Soc. Hort. Sci. 107: 604607.

7. MARINI, R.P. and J.A. BARDEN. 1987. Summer pruning of apple and peach trees. Hortic. Rev. $9: 351-375$.

8. Mochizuki, T. and S. HANAdA. 1955. The seasonal changes of the constituents of young apple trees. Part I. Water and carbohydrates. Bull. Fac. Agric. Hirosaki Univ. 1:27-38. (In Japanese with English summary)

9. PREston, A.P. and M.A. Perring. 1974. The effect of summer pruning and nitrogen on growth, cropping and storage quality of Cox's Orange Pippin apple. J. Hort. Sci. 49: 77-83.

10. SAURE, M. 1985. Der Einfluss von Schnittzeitpunkt und Schnittintensität auf Wachstum und Wunchsleistung junger Apfelbäume. Erwerbsobstbau. 27 : 169-173.

11. SAURE, M. 1987. Summer pruning effects in apple-a review. Scientia Hortic. 30: 253-282.

12. TAYLOR, B.H. and D.C. FERrEe. 1984. The influence of summer pruning and cropping on growth and fruiting of apple. J. Amer. Soc. Hort. Sci. 109: 14-24.

13. WILCKE, C. 1974. Jahresperiodische Veränderungen von Stärke und Phosphatgehalt in Wurzeln von Apfelunterlagen. p. 413-420. In: G. Hoffmann (ed.), II. International Symposium Ökologie und Physiologie des Wurzelwachstums. Akademie-Verlag, Berlin.

\section{リンゴ幼木の夏季せん定が翌年の新しょう生長に及ぼす影響}

\section{菊池卓郎・浅田武典・塩崎雄之輔・斉藤敏昭* ・鎌田晶吉** 弘前大学農学部 036 弘前市文京町 3}

\section{摘 要}

夏季せん定が冬季せん定と同様に，翌年の新しょうを 強勢にするかどうかを明らかにするため, リンゴ‘ふじ’ （台木マルバカイドウ）の奻木を用いて実験を行った。 夏季せん定の実用的場面を考慮して，㑡生新しょうを基 部 1 3 cm 残してせん去する, 間引きせん定に近いせ ん定を，全処理区において行った。

実験 1 は 1 年生樹を用い, 頂部付近の 5 本の新しょう を生長させ， 7 月上旬〜翌年 5 月下旬の 8 時期に， 4 本 の側生新しょうをせん去した。8月下旬以前のせん定区 は, 9 月下旬 3 月下旬の世九定区よりも, 翌年の新し ょう生長が弱かった. 実験 2 は主幹と 2 本の側枝より成

* 現在：青森県立藤崎園芸高等学校

** 現在：青森県立青森第三養護学校
る 2 年生樹を用い, 6 月下旬〜 11 月下旬の 6 時期に, 20 $\mathrm{cm}$ 以上の側生新しょうをせん去した。 7 月下旬以前の せん定区は，8月下旬以降のせん定区よりも，翌年の新 しょう生長が弱かった。

実験 1 における細根：新しょうの比率と，8月下旬の せん定の効果に関する実験 1 と実験 2 の結果の相違等に ついて考察し, 以下の結論を得た：夏季せん定が比較的 早くに行われ，同年内に切口付近から発生した新しょう によって細根：新しょうの比率が回復する場合は, 翌年 の新しょうは強勢化しない. 夏季せん定の時期が遅くて 上記比率が回復しない場合は, 翌年の新しょうは強勢化 する。 